\title{
ANALISIS LAJU KOROSI DENGAN ALIRAN MEDIA KOROSI HCL 10\% PADA MATERIAL BAJA ASTM A36 DENGAN SUDUT BENDING
}

\author{
Wahyu Kheren Sabyantoro *, Helmy Purwanto dan Muhammad Dzulfikar \\ Jurusan Teknik Mesin, Fakultas Teknik, Universitas Wahid Hasyim \\ Jl. Menoreh Tengah X/22, Sampangan, Semarang 50236. \\ *Wahyu Kheren Sabyantoro@gmail.com
}

\begin{abstract}
Abstrak
Kontruksi Baja yang terendam dalam keadaan air diam ataupun mengalir mudah terserang oleh korosi. Pada penelitian ini bertujuan untuk Mengetahui dan menganalisa pengaruh media pengkorosi dan aliran media pengkorosi $\mathrm{HCl} \mathrm{10 \%} \mathrm{terhadap} \mathrm{laju} \mathrm{korosi} \mathrm{pada} \mathrm{baja} \mathrm{mild} \mathrm{steel}$ A36 yang diberi perlakuan bending $60^{\circ}, 90^{\circ}, 120^{\circ}$, dan $180^{\circ}$ dengan metode celup diam dan celup putardengan waktu perendaman 30, 60, dan 90 menit. Hasil dari penelitian dan pengamatan yang diperoleh bahwa semakin kecil sudut bending maka laju korosinya akan semakin besar dan semakin lama perendaman laju korosi pada baja pun akan semakin bertambah besar. Perhitungan laju korosi ini dihitung dengan metode pengurangan beban awal dengan beban akhir. Hasil dari percobaan laju korosi pada baja ASTM A36 percobaan menggunakan metode celup putar mendapatkan nilai laju korosi yang paling besar dengan nilai $4,2367.10^{-06} \mathrm{~mm} /$ tahun waktu pencelupan 90 menit dengan sudut bending $60^{\circ}$. dan laju korosi terkecilnya terdapat pada metode celup diam dengan sudut $90^{\circ}$ waktu pencelupan 90 menit dengan nilai laju korosi sebesar 6,0524.10 $0^{-07} \mathrm{~mm} /$ tahun. Jenis korosi yang terjadi pada penelitian ini adalah korosi menyeluruh (celup diam) dan korosi sumuran (celup putar).
\end{abstract}

Kata kunci : korosi, bending, metode celup, celup putar, celup diam

\section{PENDAHULUAN}

Korosi adalah proses pengrusakan logam akibat reaksi elektrokimia antara logam dengan lingkungannya. Proses korosi terjadi secara alamiah yaitu logam kembali bersenyawa dengan oksigen sebagaimana bahan baku pada proses ekstraksi metalurgi pembuatan logam yang juga bersenyawa dengan oksigen. Sehingga korosi adalah kebalikan dari proses ekstraksi metalurgi dimana sejumlah energy yang dibutuhkan untuk proses pembuatan logam kembali dilepaskan pada proses korosi. Proses terjadinya korosi pada suatu logam membentuk suatu sel elektrokimia yang terdiri dari: anoda, katoda, larutan elektrolit dan hubungan listrik antara anoda dan katoda.

Korosi tidak bisa dihentikan namun bisa di kendalikan dengan cara melapisi logam dengan cat, oli, atau krom. Dampak dari korosi sangat merugikan Contohnya diantaranya keroposnya besi-besi penyangga pada jembatan, bocornya pipa-pipa gas, kebocoran pada lambung kapal laut, keroposnya ketel uap dan kontruksi mesin lainnya. Salah satu faktor yang mempengaruhi terjadinya korosi dalam lingkungan air adalah keberadaan elektrolit contohnya asam sulfat merupakan larutan akuatik dari gas hidrogen klorida ( $\mathrm{HCl})$. Ia adalah asam kuat, dan merupakan komponen utama dalam asam lambung.

Baja Karbon Rendah (Low Carbon Steel/mild steel) Baja karbon rendah merupakan baja dengan kandungan unsur karbon 0,008\% $0,3 \%$ C. Setiap satu ton baja karbon rendah mengandung 10-30 kg karbon. Baja karbon ini biasanya dibuat dalam bentuk plat, baja strip, dan baja batang atau progil. Baja karbon rendah ini memiliki ketangguhan dan keuletan tinggi akan tetapi memiliki sifat kekerasan dan ketahanan aus yang rendah (Rusmardi \& Feidihal, 2006). Pada umumnya baja jenis ini digunakan sebagai bahan baku untuk pembuatan komponen struktur bangunan, pipa gedung, jembatan, bodi mobil, dan lain-lainya.

Penggunaan baja karbon rendah sangat banyak salah satunya sebagai plat bahan pembuatan kapal laut dan pintu air. Pada pembuatan kapal laut plat yang digunakan adalah plat mild steel A36, dimana plat ini sering mendapat perlakuan bending, dalam pembentukan bodi kapal laut dengan proses press tentunya banyak bengkokan-bengkokan dan itu mengakibatkan retakan-retakan kecil pada plat yang bisa menimbulkan korosi. Semakin banyak retakan yang terjadi semakin besar pula resiko terjadinya korosi. 


\section{METODE PENELITIAN}

Uji komposisi dilakukan untuk mengetahui komposisi kimia yang terkandung dalam baja karbon rendah ASTM A36 yang nantinya akan digunakan untuk bahan pengujian. Proses pengujian komposisi ini dilakukan di laboratorium Politeknik Manufaktur Ceper, klaten, jawa tengah. Hasil dari pengujian ini yaitu untuk mengetahui seberapa besar unsurunsur bahan yang terkandung seperti karbon, mangan, silicon, sulfur, fosfor, dan unsur-unsur lainnya.

\section{Proses Pembuatan Spesimen}

Pada proses ini material plat baja ASTM A36 akan mendapat perlakuan tekuk (bending) dan dibentuk sesuai dengan variasi sudut-sudut yang sudah ditentukan yaitu sebesar $60^{\circ}, 90^{\circ}$, $120^{\circ}$, dan $180^{\circ}$, menggunakan ragum sebagai penjepit platsetelah itu plat di tekuk tepat pada pada $1 / 2$ dari panjang total material, menggunakan tang kombinasi dan palu dengan cara memberikan tekanan dari atas material sehingga membentuk sudut bending seperti yang sudah ditentukan.

Pada proses ini sebelumnya material yang akan di perlakukan bending terlebih dahulu material dipotong-potong menjadi 8 spesimen dengan ukuran per spesimenya adalah panjang $50 \mathrm{~mm}$ dan lebar $100 \mathrm{~mm}$. Pemotongan plat menggunakan mesin gerinda potong yang dilakukan di Laboratorium Produksi Fakultas Teknik Universitas Wahid Hasyim Semarang. Bahan yang sudah di bendingakan dibersihkan terlebih dahulu menggunakan gerinda amplas sampai permukaannya halus hal ini bertujuan untuk menghilangkan kan kotoran-kotoran dan sisa karat awal yang menempel pada spesimen, sesui dengan standar ASTM G-90 (Standart Practice for Preparing, Cleaning, and Evaluating Corrosion test specimens). Secara spesifik akan dijelaskan tentang ukuran dan pembuatan specimen seperti pada Gambar I sampai dengan Gambar 5.

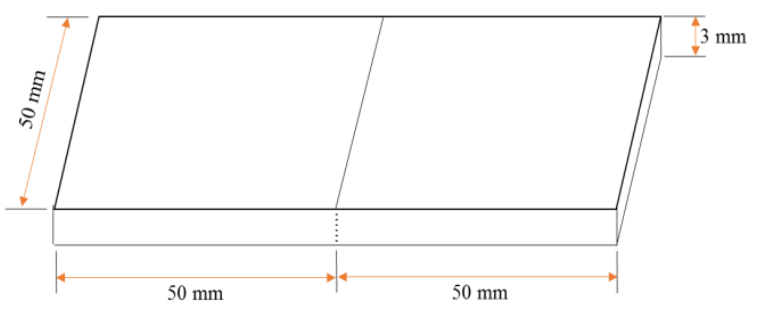

Gambar 1. Bentuk dan ukuran specimen plat ASTM A36

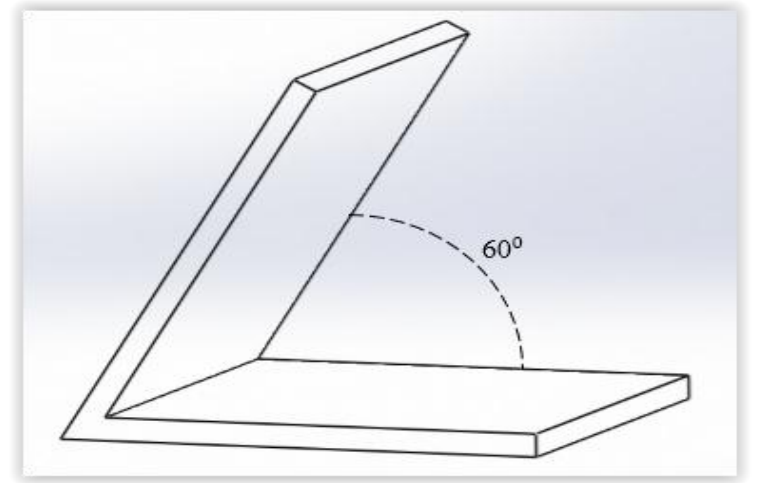

Gambar 2. Bentuk spesimen uji dengan sudut bending $\mathbf{6 0}^{\circ}$

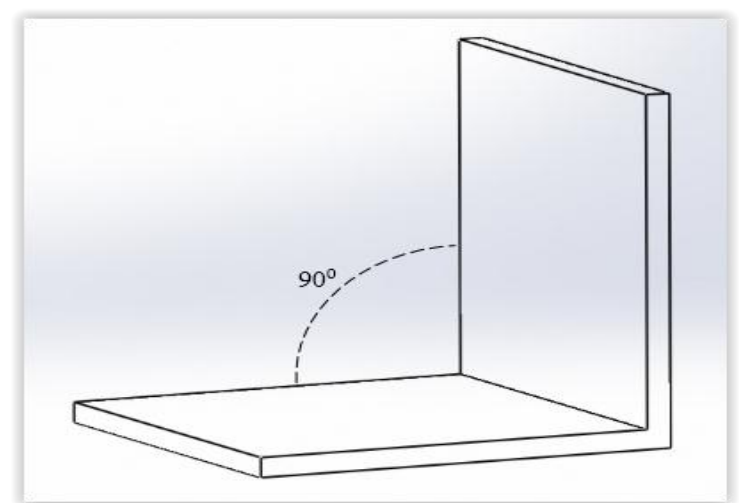

Gambar 3 Bentuk spesimen uji dengan sudut bending $\mathbf{9 0}^{\circ}$

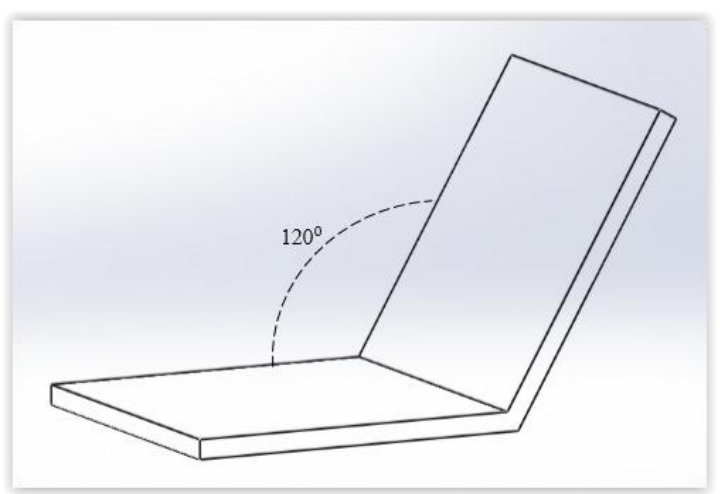

Gambar 4. Bentuk spesimen uji dengan sudut bending $\mathbf{1 2 0}^{\circ}$

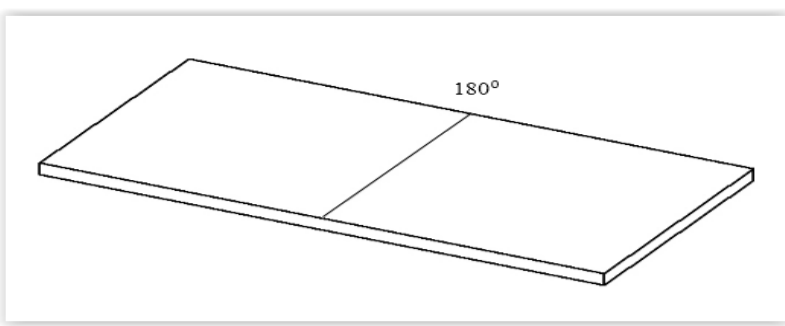

Gambar 5 Bentuk spesimen uji dengan sudut bending $\mathbf{1 8 0}^{\circ}$ 


\section{Analisis pengujian korosi}

Untuk mengetahui tingkat korosifitas pada plat baja ASTM A36 maka pada penelitian ini menggunakan media larutan pengkorosi asam klorida $\mathrm{HCl}$ dengan konsentrasi sebesar $10 \%$ dengan variasi perendaman selama 30 menit, 60 menit, dan 90 menit. Tahapan dari penelitian ini adalah:

1. Penimbangan berat awal Spesimen

Pada tahap penimbangan, spesimen yang sudah dipotong-potong menjadi 8 bahan uji dan sudah melalui tahap bending serta dibersihkan dengan amplas dari sisa kotoran dan karat, spesimen akan ditimbang berat awal dahulu sebelum proses perendaman pada larutan asam klorida $\mathrm{HCl}$.

2. Mempersiapkan larutan pengkorosi $\mathrm{HCl}$

Menyiapkan larutan asam klorida $\mathrm{HCl}$ murni sebanyak 1.041,6 ml dengan air murni sebanyak 8.958,33 ml, sehingga diperoleh perbandingan $\mathrm{HCl} 10 \%$ dengan air murni $90 \%$. Karena asam sulfat yang dijual di pasaran hanya dengan konsentrasi $96 \%$ sedangkan konsentrasi yang dibutuhkan sebanyak 10\% maka untuk pembuatan larutannya menggunakan rumus sebagai berikut:

$\mathrm{V}_{1} \cdot \mathrm{C}_{1=} \mathrm{V}_{2} \cdot \mathrm{C}_{2}$

\section{Perendaman spesimen}

Perendaman atau uji celup yang digunakan dalam pengujian korosi ini dilakukan sesuai dengan prosedur ASTM G 31-72 (standard recommended practice forlaboratory immersion corrosion testing of metal).Perendaman spesimen dibagi menjadi 3 variasi waktu yaitu 30, 60, dan 90 menit. Untuk tahap perendaman pertama mempersiapkan 4 buah bak/ember plastik yang telah diberi air $90 \%$ dan di campur larutan pengkorosi yaitu $\mathrm{HCl}$ sebanyak $10 \%$. Setelah itu masukan spesimen kedalam ember tersebut sesuai waktu yang sudah ditentukan lalu tutup bagian atas ember, ini bertujuan agar tidak ada unsur luar yang masuk selama proses perendaman berlangsung.

4. Penimbangan berat akhir

Pada tahap akhir pengujian yaitu dengan mengeluarkan spesimen dari bak/ember plastik yang berisi larutan $\mathrm{HCl}$, lalu bersihkan dan keringkanspesimen, kemudian lakukan penimbangan akhir untuk menghitung pengurangan berat setelah pengujian.

\section{Langkah-langkah penelitian}

Langkah-langkah penelitian seperti yang dapat di jelaskan sebagai berikut :

1. Menyiapkan peralatan dan bahan.

2. Melakukan proses bending pada specimen.

3. Membersihkan permukaan spesimen dari kotoran dan sisa-sisa karat.

4. Menimbang berat awal dari spesimen.

5. Menyiapkan media larutan pengkorosinya yaitu $\mathrm{HCl}$ sebanyak $10 \%$ yang di campur dengan aquades.

6. Melekukan proses perendaman spesimen selama 30, 60, dan 90 menit dengan pecelupan dian dan putar.

7. Mengeluarkan spesimen uji setelah perendaman untuk dibersihkan dan dikeringkan.

8. Menimbang berat akhir spesimen uji.

9. Melakukan pengamatan menggunakan foto makro.

10. Analisis data dan kesimpulan

\section{HASIL DAN PEMBAHASAN Pengujian Laju Korosi}

Dari data pengujian komposisi material yang digunakan dalam penelitian ini diketahui bahwa kadar karbon yang terkandung pada baja tersebut adalah $0,0324 \%$. Dengan kandungan karbon yang mencapai $0,0324 \%$ maka baja jenis Mild Steel ASTM A36 termasuk kategori low carbon steel atau baja karbon rendah, karena baja karbon rendah itu sendiri kandungan karbonya maksimal hanya 0,3\% (Rusmadi dan Feidihal, 2006).

\section{Hasil pengujian laju korosi $\mathrm{HCl} 10 \%$ dalam keadaan diam}

Hasil besarnya laju korosi pada baja mild steel ASTM A36 yang mendapat perlakuan variasi bending $60^{\circ}, 90^{\circ}, 120^{\circ}$, dan $180^{\circ}$, dengan metode pengujian larutan pengkorosi yaitu $\mathrm{HCl}$ $10 \%$ dalam keadaan diam. Pada pengujian ini di peroleh data bahwa laju korosi yang di dapat pada waktu pencelupan 30 menit dengan sudut bending $60^{\circ}$ adalah $1,8762.10^{-05} \mathrm{~mm} / \mathrm{tahun}$, dan pada waktu 60 menit variasi sudut bending $60^{\circ}$ laju korosi sebesar $3,0262.10^{-06} \mathrm{~mm} / \mathrm{tahun}$, sedangkan pada variasi sudut bending $60^{\circ}$ dengan waktu perendaman 90 menit laju korosinya sebesar $1,0087.10^{-06} \mathrm{~mm} / \mathrm{tahun}$ atau mengalami kenaikan sekitar 5\%. Percobaan dengan media pengkorosi dalam keadaan diam di dapat nilai laju korosi yang paling besar adalah $1,8762.10^{-05} \mathrm{~mm} /$ tahun dengan sudut bending $60^{\circ}$ dan waktu pencelupan 30 menit 
sedang laju korosi terkecilnya yaitu pada sudut $90^{\circ}$ dengan waktu pencelupan 90 menit nilai laju korosinya sebesar $6,0524 \cdot 10^{-07}$. Untuk lebih jelasnya bisa dilihat dalam bentuk grafik hasil uji korosi dengan media pengkorosi dalam keadaan celup diam pada Gambar 6.

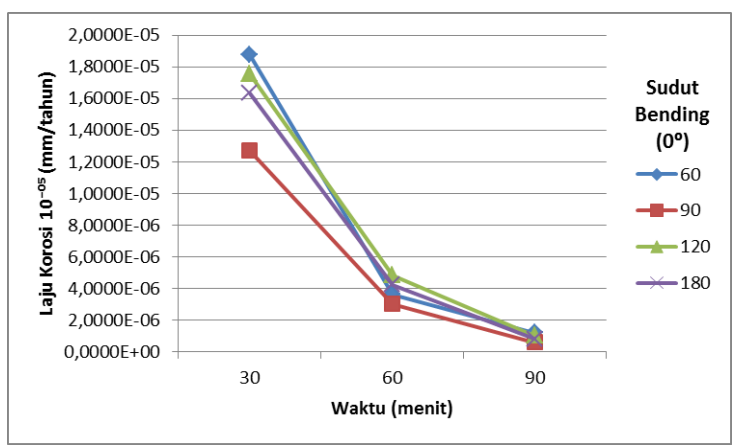

\section{Gambar 6 Grafik metode celup diam}

Berdasarkan dari data grafik Gambar 6. menunjukan bahwa laju korosi pada saat bending $60^{\circ}, 90^{\circ}, 120^{\circ}$, dan $180^{\circ}$ dengan konsentrasi larutan $\mathrm{HCl} \quad 10 \%$ mengalami penurunan seiring dengan lamanya waktu pencelupan. Terlihat jelas laju korosi terbesar terjadi pada waktu 30 menit pencelupan, dengan kondisi larutan $\mathrm{HCl}$ dalam keadaan diam terdapat pada spesimen dengan sudut bending $60^{\circ}$ laju korosinya sebesar $1,8762.10^{-05}$ $\mathrm{mm} / \mathrm{tahun}$, pada sudut bending $120^{\circ}$ dengan waktu 30 menit mengalami penurunan sekitar $1 \%$ dari sudut bending $60^{\circ}$ dengan nilai laju korosi sebesar 1,7552.10 $0^{-05} \mathrm{~mm} /$ tahun. Sedangkan pada sudut bending $90^{\circ}$ dan $180^{\circ}$ waktu perendaman 30 menit juga mengalami penurunan yaitu $1,6341.10^{-05} \mathrm{~mm} / \mathrm{tahun}$ pada sudut $90^{\circ}$ dan $1,2710.10^{-05} \mathrm{~mm} /$ tahun pada sudut $180^{\circ}$.

Pengujian pencelupan metode celup diam pada sudut $60^{\circ}$ dengan waktu pencelupan 90 menit nilai korosinya sebesar $1,0087.10^{-06}$ $\mathrm{mm} /$ tahun mengalami penurunan sekitar $8 \%$ dari waktu sebelumnya yaitu 60 menit dengan sudut bending yang sama $60^{\circ}$. Laju korosi terkecil pada waktu pencelupan 90 menit dengan sudut bending $90^{\circ}$ sebesar 6,0524.10 $\mathrm{mm} / \mathrm{tahun}$, dan laju korosi terbesarnya adalah $1,2105.10^{-06} \mathrm{~mm} /$ tahun terdapat pada sudut bending $120^{\circ}$ dengan waktu pencelupan 90 menit. Sedangkan laju korosi pada sudut $90^{\circ}$ pada pencelupan selama 90 menit nilainya sebesar $6,0524.10^{-07} \mathrm{~mm} /$ tahun naik dari percobaan sebelumnya yaitu 60 menit pada sudut yang sama.
Dari percobaan ini dapat diketahui bahwa semakin lama waktu pencelupan menyebabkan tingkat laju korosi pada baja ASTM A36 laju korosinya kecil, jadi pada waktu pengujian 60 dan 90 menit laju korosinya menurun seiring bertambahnya waktu. Seperti penelitian yang dilakukan Permadi \& Palupi, (2014) yang menyatakan bahwa semakin lama waktu pencelupan maka nilai laju korosinya akan menurun pada gambar grafik IV.2 dapat diamati laju korosi spesimen saat uji celup diam dengan larutan pengkorosi asam klorida $\mathrm{HCl}$ dengan konsentrasi $10 \%$ terlihat jelas laju korosi terbesarnya terjadi pada waktu 30 menit pencelupan dan terjadi pada spesimen dengan sudut $60^{\circ}$. Pada pengujian celup diam 60 menit laju korosinya semakin menurun seiring dengan bertambahnya waktu pencelupan, walaupun tingkat penurunanya tidak signifikan.

Laju korosi terbesar pada waktu 60 menit terjadi pada sudut bending $120^{\circ}$ dan laju korosi terkecil pada sudut bending $90^{\circ}$. Semakin lama perendaman laju korosi akan semakin menurun dan laju korosi terbesar terjadi di awal proses perendaman, yaitu pada menit pertama pada variasi waktu perendaman (Permadi dan Palupi, 2014). Sedangkan pada waktu pencelupan 90 menit laju korosi juga menurun, lebih kecil jika di bandinkan dengan waktu 60 menit. Pada sudut bending $60^{\circ}$ merupakan laju korosi terbesar pada waktu pencelupan 90 menit dan laju korosi terkecil terdapat pada sudut bending $90^{\circ}$. Banyak sedikitnya konsentrasi $\mathrm{HCl}$ juga mempengaruhi besarnya laju korosi.

Dalam metode celup diam terjadi korosi menyeluruh seperti ditinjukkan pada Gambar 7.

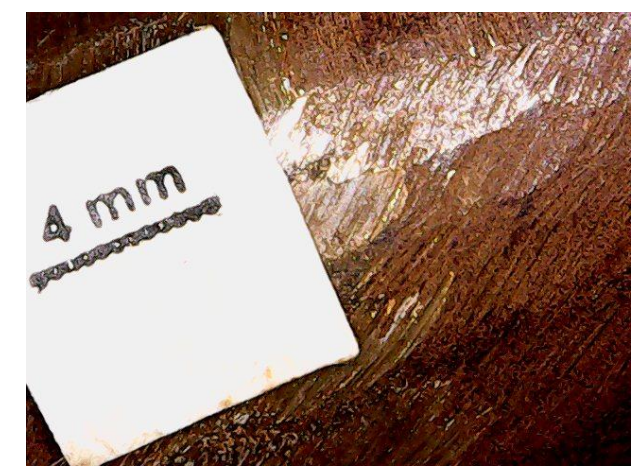

Gambar 7. Korosi menyeluruh (Uniform corrosion)

Pada gambar IV.3 kerusakan permukaan terkorosi jelas terlihat dengan 
berubahnya warna dari baja ASTM A36 tersebut menjadi kecoklatan. Dari gambar diatas terlihat sebagian yang terkena korosi sudah tidak rata lagi bentuk permukaan agak kasar karena molekul atom sudah berubah ikatanya. Dari perubahan warna dan perubahan fisik diatas maka korosi yang terjadi pada pengujian korosi metode celup diam ini adalah Korosi menyeluruh (Uniform corrosion). Korosi menyeluruh (Uniform corrosion) adalah korosi yang terjadi pada permukaan logam secara merata. Sehingga ketebalan logam berkurang sebagai akibat permukaan terkonversi oleh produk karat. Cara pencegahan dengan melakukan pelapisan menggunakan cat atau dengan material yang lebih anodik.

\section{Hasil pengujian laju korosi $\mathrm{HCl} 10 \%$ dalam keadaan berputar}

Hasil uji dan perhitungan laju korosi pada spesimen baja karbon rendah ASTM A36 yang di celup dalam larutan asam klorida $\mathrm{HCl}$ dengan konsentrasi $10 \%$ laju korosinya cenderung mengalami penurunan akan tetapi pada rentan waktu pencelupan 60 menit sampai 90 menit tingkat penurunan berat yang hilang (weight loss) cenderung setabil, hanya selisih beberapa angka saja akan tetapi pada pencelupan pertama yaitu waktu 30 menit berat yang hilang mengalami peningkatan. Misalkan pada waktu pencelupan 30 menit dengan sudut bending $60^{\circ}$ mengalami kenaikan berat yang hilang sebesar 0,31 gram saja atau dengan nilai laju korosi sebesar $1,8762.10^{-05} \mathrm{~mm} / \mathrm{tahun}$ lebih besar jika dibandingkan dengan sudut $90^{\circ}$ dengan laju korosi sebesar 1,2710.10-05 $\mathrm{mm} /$ tahun. Sedangkan pada sudut $120^{\circ}$ dan $180^{\circ}$ nilai laju korosinya cenderung sama yaitu sebesar $1,6431.10^{-05} \mathrm{~mm} /$ tahun sedangkan sudut $180^{\circ}$ nilai laju korosinya sebesar $1,6341.10^{-05} \mathrm{~mm} /$ tahun. Artinya ini nilainya sama jika di bandinkan dengan sudut $120^{\circ}$.

Pencelupan waktu 60 menit dengan sudut bending $60^{\circ}$ mengalami penurunan dari waktu sebelumnya 30 menit dengan selisih berat yang hilang (weight loss) hanya 0,15 gram saja dengan nilai laju korosi sebesar 4,8419.10 $\mathrm{mm} /$ tahun. Sedangkan laju korosi terkecil yaitu pada sudut bending $120^{\circ}$ dengan nilai laju korosi sebesar $4,2367.10^{-06} \mathrm{~mm} / \mathrm{tahun}$. Laju korosi cenderung tidak setabil pada waktu pencelupan menit ke 90 , pada sudut $120^{\circ}$ laju korosinya $4,2367.10^{-06} \mathrm{~mm} /$ tahun ini merupakan laju korosi terbesar pada menit 90. Laju korosi terkecil terdapat pada sudut $90^{\circ}$ dengan nilainya sebesar $2,4210.10^{-06} \mathrm{~mm} /$ tahun .

Data hasil pengujian laju korosi pada baja ASTM A36 dengan media pengkorosi dalam keadaan berputar dapat dilihat dalam bentuk grafik pada Gambar 8 .

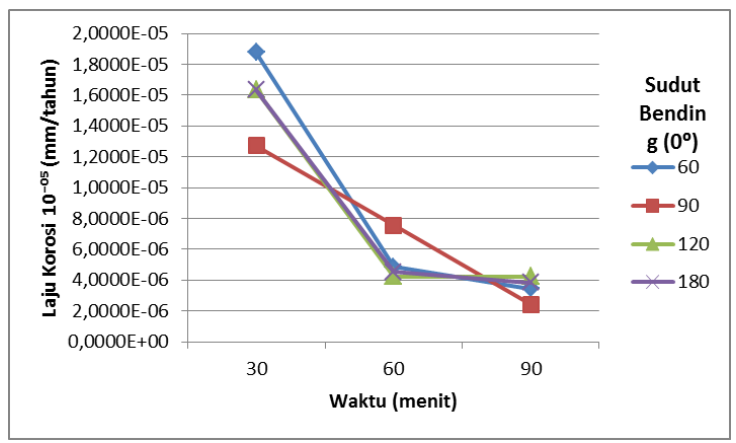

\section{Gambar 8 Grafik metode celup putar}

Gambar 8 menggambarkan adanya penurunan laju korosi seiring dengan naiknya waktu pengujian. Pengujian dengan konsentrasi asam klorida $10 \%$ selama 30 menit laju korosinya tidak mengalami peningkatan artinya ini hampir sama dengan pengujian pertama yaitu pada metode celup diam saat pencelupan 30 menit jadi tidak ada selisih angka antara pengujian menit pertama metode celup diam dengan menit pertama metode celup putar. Pada penelitian ini media aliran korosi (metode celup putar) kurang berpengaruh terhadap laju korosi. Laju korosi terbesar pada pengujian 30 menit adalah pada sudut $60^{\circ}$ dengan nilai sebesar $1,8762.10^{-05} \mathrm{~mm} / \mathrm{tahun}$ dan laju korosi terkecilnya adalah $1,2710.10^{-05} \mathrm{~mm} /$ tahun sudut bending $90^{\circ}$ kecilnya laju korosi tersebut dikarenakan pada sudut $90^{\circ}$ baja ASTM A36 ini hanya sedikit mengalami gaya tekan. Karena semakin sedikitnya gaya tekan yang bekerja pada baja tersebut maka nilai korosinya akan semakin kecil sebab compress maupun tensile (gaya tarik) yang diterima tidak ada (Putri, dkk, 2012). Pada pencelupan sudut bending $180^{\circ}$ dengan waktu 30 menit nilai laju korosinya $1,6341.10^{-05} \mathrm{~mm} /$ tahun dan laju korosi pada sudut bending $120^{\circ}$ nilainya sebesar $1,6341.10^{-}$ ${ }_{05} \mathrm{~mm} / \mathrm{tahun}$ sebanding dengan sudut $180^{\circ}$ dengan menit 30 .

Waktu perendaman 60 menit laju korosi mengalami tingkat penurunan yang derastis misalkan pada sudut bending $60^{\circ}$ nilai laju korosinya $4,8419.10^{-06} \mathrm{~mm} /$ tahun tidak sebanding dengan pencelupan menit pertama. Seperti terlihat pada grafik IV.3 pencelupan 
dengan sudut bending $90^{\circ}$ waktu perendaman 60 menit tingkat penurunan laju korosinya cenderung setabil yaitu sebesar 7,5655.10 $\mathrm{mm} / \mathrm{tahun}$ akan tetapi pada sudut bending $120^{\circ}$ laju korosi mengalami penurunan dengan nilai sebesar $4,2367.10^{-06} \mathrm{~mm} /$ tahun begitu juga pada sudut $180^{\circ}$ juga mengalami penurunan dengan nilai sebesar $4,5393.10^{-06} \mathrm{~mm} /$ tahun.

Pada waktu pencelupan 90 menit laju korosi terbesar terdapat pada sudut bending $120^{\circ}$ dengan nilai laju korosi $4,2367.10^{-06} \mathrm{~mm} /$ tahun dengan laju korosi terkecilnya pada sudut $90^{\circ}$ dengan nilai laju korosi $2,4210.10^{-06} \mathrm{~mm} /$ tahun. Terjadi karena semakin banyaknya konsentrasi larutan $\mathrm{HCl}$ maka tingkat pengikisan pada baja semakin bertambah cepat.

Berdasarkan Gambar 8 untuk pengujian laju korosi dalam keadaan celup putar laju korosi terbesarnya terdapat pada menit awal pencelupan yaitu 30 menit ini dikarenakan konsentrasi $\mathrm{HCl}$ pada awal pencelupan masih dalam keadaan seperti awal yaitu dengan konsentrasi larutan 10\%, artinya kadar keasamannya masih tinggi. Pada penelitian ini semakin bertambahnya waktu perendaman nilai laju korosinya semakin menurun.

Dalam metode celup (putar) / mengalir terjadi korosi sumuran (pitting corrosion) seperti yang ditunjukkan pada Gambar 9.

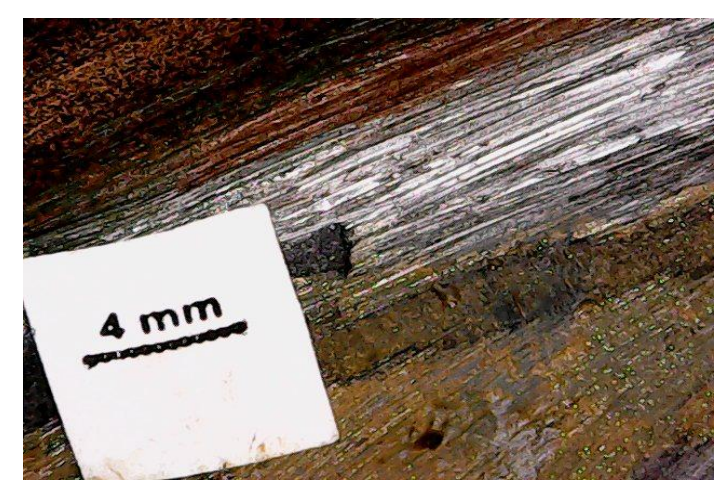

\section{Gambar 9 Korosi sumuran (pitting corrosion)}

Pada Gambar 9 spesimen yang direndam dalam media pengkorosi asam klorida $(\mathrm{HCl})$ pada metode celup putar mengalami korosi yang ditandai dengan lubang kecil ke arah dalam pada permukaan logam. Hal ini disebabkan adanya mekanisme autokatalitic yang menghasilkan larutan yang pekat dan berat. Larutan ini tinggal di dalam sumuran atau lubang dan menjadi sarana terjadinya serangan korosi selanjutnya. Hal ini juga bisa disebabkan karena adanya cacat pembuatan spesimen dan ini merupakan jenis korosi sumuran (pitting corrosion).

Korosi sumuran (pitting corrosion) yaitu korosi yang berbentuk lubang-lubang pada permukaan logam karena hancurnya film dari proteksi logam, yang disebabkan oleh rate korosi yang berbeda antara satu tempat dengan tempat lainnya pada permukaan logam tersebut. Cara pengendalian korosi ini dengan menghindari permukaan logam dari goresan, memperhalus permukaan logam, dan menghindari komposisi material dari berbagai jenis logam.

\section{Perbandingan Laju Korosi Metode Celup Diam Dengan Metode Celup Putar.}

Data hasil perbandingan pengujian laju korosi baja ASTM A36 menggunakan media pengkorosi $\mathrm{HCl} 10 \%$ dengan metode celup diam dan metode celup putar dapat dilihat pada Gambar 10

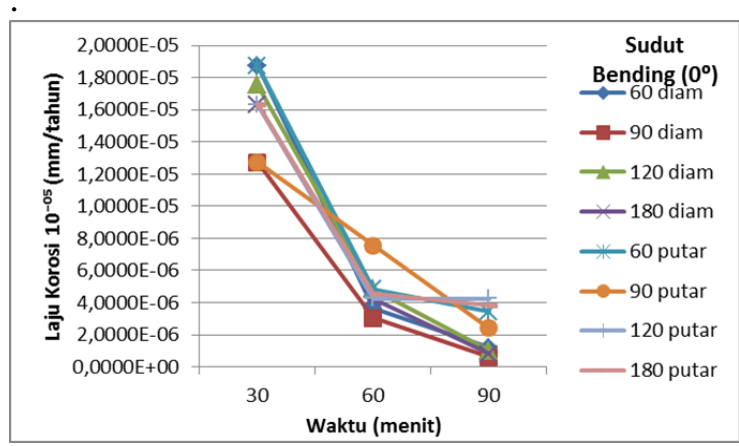

Gambar 10 Grafik perbandingan metode celup diam dan metode celup putar

Berdasarkan data dan diagram perbandingan laju korosi pada baja karbon rendah mild steel ASTM A36 dengan menggunakan metode celup diam dan celup putar/mengalir yang di beri perlakuan bending menunjukkan bahwa laju korosi terbesar terjadi pada sudut bending $60^{\circ}$. Untuk perendaman dalam larutan $\mathrm{HCl}$ konsentrasi $10 \%$ nilai laju korosi pada metode celup putar atau mengalir lebih tinggi jika dibandingkan dengan nilai laju korosi metode celup diam, dikarenakan laju aliran media korosi $\mathrm{HCl}$ sangat mempengaruhi nilai laju korosi tersebut. Sesuai dengan penelitian yang telah dilakukan oleh Utomo, (2009) Hal yang mempengaruhi terjadinya korosi adalah kecepatan aliran, jika kecepatan aliran semakin cepat maka akan merusak lapisan film pada logam sehingga akan mempercepat korosi karena logam akan kehilangan lapisan. 
Pada saat metode celup diam hasil laju korosinya lebih kecil jika dibandingkan dengan laju korosi metode celup putar ini disebabkan juga karena pengaruh temperatur sekitar, karena juga sangat berpengaruh terhadap laju korosi. Utomo, (2009) menyatakan semakin tinggi temperatur maka reaksi kimia akan semakin cepat, sehinggga laju korosi akan cepat terjadi pula.

Waktu pencelupan 90 menit pada metode celup putar atau mengalir terjadi laju korosi paling tinggi yaitu pada spesimen yang diberi perlakuan bending $60^{\circ}$ dikarenakan waktu pencelupan yang lebih lama dibanding pencelupan spesimen yang lain. Semakin lama waktu pencelupan spesimen maka, semakin besar pula laju korosinya. Semakin lama waktu pengujian menyebabkan proses pengikisan pada baja menjadi bertambah besar (Ridluwan, 2007).

Dari keseluruhan pengujian antara metode celup diam dan metode celup putar laju korosi terbesarnya terdapat pada sudut bending $60^{\circ}$ dengan waktu perendaman 30 menit. Sudut bending sangat berpengaruh terhadap laju korosi pada sebuah spesimen, semakin kecil sudut bending maka laju korosinya akan semakin besar, ini dikarenakan pori-pori atau lapisan spesimen semakin terbuka dan itu memberikan pengaruh terhadap proses terjadinya korosi. (Permadi dan Palupi, 2014).

\section{KESIMPULAN}

Dari hasil penelitian dan pembahasan yang telah dilakukan dapat disimpulkan bahwa.

1. Pengaruh media pengkorosi $\mathrm{HCl}$ terhadap laju korosi pada mild steel A36 yang di beri perlakuan bending yaitu Sudut bending sangat berpengaruh terhadap laju korosi pada sebuah spesimen, semakin kecil sudut bending maka laju korosinya akan semakin besar.

2. Bagaimana pengaruh aliran media pengkorosi $\mathrm{HCl}$ terhadap laju korosi pada baja mild steel A36 yang diberi perlakuan bending yaitu semakin lama pencelupan spesimen maka semakin besar laju korosi spesimen tersebut. Nilai laju korosi terbesar terjadi pada spesimen yang diberi perlakuan bending $60^{\circ}$ dengan menggunakan metode putar pada perendaman 30 menit dengan nilai laju korosi sebesar $1,8762.10^{-05} \mathrm{~mm} /$ tahun
Untuk penelitian selanjutnya lakukanlah pengujian di setiap spesimen dengan suhu temperatur yang sama.

\section{DAFTAR PUSTAKA}

Adrian. (2009). Perilaku korosi material baja paduan akibat pengaruh kondensat yang berasal dari pembangkit listrik tenaga panas bumi. Jakarta: (Doctoral Thesis FMIPA Universitas Indonesia, 2009).

Fontana, M. (1987). Corrosion Engineering, 3 ed,. New York: Mc. Graw Hill Book Company.

Hermawan, B. (2012). Pengaruh Posisi Pengelasan dan Ketebalan Pelat Terhadap Sifat Mekanis Dan Struktur Mikro Dari Sambungan Dissimilar Metal Stainless Steel 304 dan Carbon Steel A36. Depok: Fakultas Teknik Universitas Indonesia.

Hidayat, A. R., Rochani, I., \& Supomo, H. (2013). Studi Eksperimen Perbandingan Laju Korosi Pada Plat ASTM (American Society For Testing and Material) A36 Dengan Menggunakan Variasi Sudut Bending. Jurnal Teknik Pomits, 56-60, Vol 2, No 1.

Permadi, L. B., \& Palupi, A. E. (2014). Analisa Laju Korosi Pada Baja Karbon Rendah (Mild Steel) Dengan Perlakuan Bending Pada Media Pengkorosi Larutan Asam. JTM Universitas Negeri Surabaya, 49-54, Vol 3, No 1.

Putri, A. M., Rochani, I., \& Supomo, H. (2012). Studi Laju Korosi dan Surface Morfologi Pipa Bawah Laut API 5L Grade X65 dengan Variasi Sudut Bending. Jurnal Teknik ITS, 198-202, Vol 1, ISSN: 2301 -9271.

Rusmardi, \& Feidihal. (2006). Analisa Persentase Kandungan Karbon Pada Logam Baja. Jurnal Teknik Mesin Politeknik Negeri Padang, 36-43, Vol 3, No 1.

Sulaiman. (2010). Pengaruh Proses Pelengkungan Dan Pemanasan Garis Pelat Baja Kapal Aisi-E 2512 Terhadap Nilai Kekerasan Dan Laju Korosi. (Tesis): Program Pasca Sarjana Universitas Diponegoro 2010, Semarang.

Threthewey, K. R. (1991). Korosi Untuk Mahasiswa Sains dan Rekayasa. Jakarta: PT Gramedia Pustaka Utama. Hlm 63-89.

Utomo, Budi (2009). Jenis Korosi Dan Penanggulangannya. Teknik Perkapalan Universitas Diponegoro, KAPAL, Vol 6, No $2,138-141$. 